\title{
Implementation of Tax Incentives to Avoid Unemployment Caused by the Economic Situation due to the COVID-19 Health Emergency in Mexico
}

\author{
Mariangel Salazar \\ Autonomous University of Queretaro. Email: mariangelsalazarsoto@gmail.com
}

\begin{abstract}
Since the end of March 2020 millions, as the COVID-19 pandemic emerged as a health emergency, working people had to stay at home, telework or had to face consequences of the crisis such as low wages or layoffs. ${ }^{i}$ In Mexico unemployment became a major problem for the economy. Although the country took measures to contain the imp act of the pandemic on the labor market, these have not been sufficient; the development and implementation of activities that create incentive or promotions are indispensable components of the recovery or sustainability of industries in times of crisisii. According to Article 25 of the Political Constitution of Mexicoiii, the State is responsible for guiding national development and ensure that it is comprehensive and sustainable; the State shall, according to the Constitutional provision, ensure the stability of public finances and the financial system to help generate favorable conditions for economic growth and

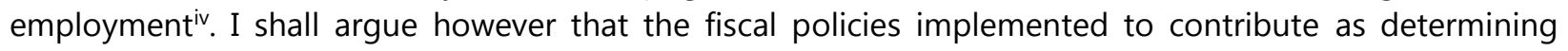
factors in the sector of growing unemployment due to the COVID-19 pandemic have not been adequate even though the optimal measures were being taken under a more socialist system of governance in place during the two years.
\end{abstract}

Keywords: Unemployment, COVID 19, national development, economic growth, Tax Incentives, Mexico

\section{Introduction}

The reduction in economic activity caused by the health emergency of the COVID-19 pandemic affected a labor market that was already weakened by gaps created over the years by discriminatory access and the standards and quality of employment. The first months of the pandemic saw a massive outflow of people from the labor force and the loss of millions of formal and informal jobs. The unemployment rate rose to $5.5 \%$ in June 2020, whereas at the end of April of this year it has increased by a record number of an additional 574,000 unemployed people as compared to the statistics for the same month in 2020. ${ }^{\vee}$ The total number of unemployed people is 2.7 million people according to the latest National Employment Survey of the National Institute of Statistics and Geography (ENOE - INEGI 2020). Mexico, like several other Latin American countries, is going through an economic crisis; in recent decades it has grown rapidly due to the economic conditions of the country, implementation of inequitable policies and the lack of promotion or incentives. Employment is of general interest for the Mexican state ${ }^{\mathrm{vi}}$, in addition to

This Open Access article is published under a Creative Commons Attribution Non-Commercial 4.0 International License (http://creativecommons.org/licenses/by-nc/4.0/), which permits non-commercial re-use, distribution, and reproduction in any medium, provided the original work is properly cited. For citation use the DOI. For commercial re-use, please contact editor@rupkatha.com. 
what is established in Article 25 of the Constitution regarding the obligation of the State to generate favorable conditions for economic growth and employment. Article 123 states that everyone has the right to decent and socially useful work, and to this effect, the creation of jobs

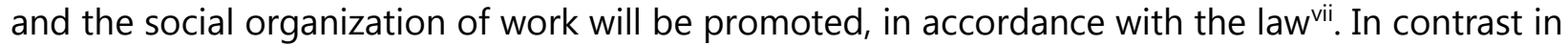
2020, countries such as Germany and Italy, that granted fiscal support close to $40 \%$ of their Gross Domestic Product (GDP) to labour welfare, Mexico granted the least stimulus to try to limit the impact of the closure of economic activities due to the pandemic. This information comes from an analysis of the International Institute of Finance of the International Monetory Fund, where it is sated that fiscal support that represented less than $1 \%$ of GDP has been utilized for the industrial generation of the economy. viii

\section{Did Subsidies Incentivise the Work Force?}

If the negative impacts of the pandemic were to be contained, the employability would depend on generating the conditions for a more consistent and broad-based revival of economic

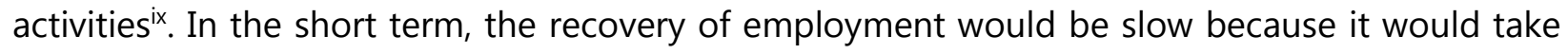
time to reestablish the growth of productive and commercial activity to the levels existing prior to the appearance of COVID-19. However, Mexico, by promoting effective incentive or development activities, specifically appropriate fiscal stimuli, might have been be able to slow down and even reduce unemployment; it is possible that with such incentives, companies, industries and employers could find it beneficial to retain their workforce, and thus the State might have guaranteed in this way the right to employment and benefits for society. The State of Yucatan represents an exception since it could reduce its unemployment rate by -0.99 points: from $3.38 \%$ to $2.39 \%$.

\section{Context: Contingency and Subsidy}

Economic crises and recessions tend to destroy the productive infrastructures that demand labor, directly affecting the increase in unemployment and the loss of family income; consequently, poverty spreads due to unsatisfied basic needs and the worsening of the population's standard of living, especially in the most vulnerable rural sectors ${ }^{x}$. Unemployment is defined by the ILO as the set of individuals of working age who in specified reference periods present three characteristics: these are that (1) they are without work (2) these people are either available for work and / or are looking for work ${ }^{\mathrm{xi}}$. In Mexico, according to ILO estimates, the sectors most strongly affected by COVID-19 are: manufacturing industries, wholesale and retail trade, real estate services, and accommodation and food and beverage services ${ }^{x i i}$. Taking into account what

Samaniego ${ }^{\text {xiii }}$ establishes and applying it to the case of unemployment, we can say that reducing unemployment requires not only a sustained increase in the growth rate and productivity levels of the economy, but also an improvement in the regulations and administrative activities that prevail in the labor market. Incentive or promotion activities are actions of the public administration that consist of stimulating, through prizes or support, the exercise of the activity of individuals so that it is oriented to protect or promote the fulfillment of purposes of general interest or public needs without the use of coercion or the creation of public services. One of these 

Implementation of Tax Incentives to Avoid Unemployment Caused by the Economic Situation due to the COVID-19 Health Emergency in Mexico

activities of promotion are the fiscal incentives. Several Mexican states have announced fiscal support and incentives to address the economic impact that the COVID-19 contingency is having on the business sector. The following is a summary of some examples of the most relevant support and fiscal incentives for the business sector that have been published in the official newspapers of the States ${ }^{\mathrm{xiv}}$.

\begin{tabular}{|c|c|c|c|c|}
\hline \multirow{2}{*}{ Federal Entity } & \multirow{2}{*}{$\begin{array}{c}\text { Tax Roll Back/ Other } \\
\text { Incentives }\end{array}$} & \multicolumn{3}{|c|}{ Percentaje Effects on Employement } \\
\hline & & TOTAL 2019 & TOTAL 2020 & Decrease \\
\hline Aguascalientes & Incentivized & 3.53 & 4.25 & 0.72 \\
\hline Baja California & No Incentives & 2.56 & 2.60 & 0.04 \\
\hline Baja California & Incentivized & 4.18 & 5.06 & 0.88 \\
\hline Campeche & No Incentives & 3.30 & 3.91 & 0.61 \\
\hline Chiapas & No Incentives & 3.26 & 3.53 & 0.27 \\
\hline Chihuahua & Incentivized & 3.03 & 4.36 & 1.33 \\
\hline Ciudad de México & No Incentives & 4.99 & 6.02 & 1.03 \\
\hline Coahuila de Zaragoza & No Incentives & 4.54 & 9.43 & 4.89 \\
\hline Colima & Incentivized & 3.54 & 3.80 & 0.26 \\
\hline Durango & Incentivized & 3.87 & 4.92 & 1.05 \\
\hline Guanajuato & No Incentives & 3.66 & 5.99 & 2.33 \\
\hline Guerrero & No Incentives & 1.51 & 2.96 & 1.45 \\
\hline Hidalgo & Incentivized & 2.42 & 2.22 & -0.26 \\
\hline Jalisco & $\begin{array}{c}\text { Incentivized } \\
.\end{array}$ & 2.99 & 3.96 & 0.97 \\
\hline Estado de México & Incentivized & 4.55 & 6.19 & 1.64 \\
\hline $\begin{array}{c}\text { Michoacán de } \\
\text { Ocampo }\end{array}$ & Incentivized & 2.69 & 3.71 & 1.02 \\
\hline Morelos & Incentivized & 2.33 & 2.55 & 0.22 \\
\hline Nayarit & $\begin{array}{c}\text { Incentivized } \\
.\end{array}$ & 3.91 & 4.55 & 0.64 \\
\hline Nuevo León & Incentivized & 3.49 & 4.84 & 1.35 \\
\hline Oaxaca & Incentivized & 1.78 & 2.91 & 1.13 \\
\hline Puebla & Incentivized & 2.66 & 4.94 & 2.28 \\
\hline Querétaro & Incentivized & 4.33 & 5.82 & 1.49 \\
\hline Quintana Roo & Incentivized & 3.04 & 6.44 & 3.4 \\
\hline San Luis Potosí & Incentivized & 2.58 & 3.29 & 0.71 \\
\hline
\end{tabular}




\begin{tabular}{|c|c|c|c|c|}
\hline Sinaloa & No Incentives & 3.20 & 3.46 & 0.26 \\
\hline Sonora & Incentivized & 4.26 & 5.65 & 1.39 \\
\hline Tabasco & No Incentives & 7.09 & 6.36 & -0.73 \\
\hline Tamaulipas & Incentivized & 3.43 & 3.26 & -0.17 \\
\hline Tlaxcala & No Incentives & 3.73 & 5.90 & 2.17 \\
\hline $\begin{array}{c}\text { Veracruz de Ignacio } \\
\text { de la Llave }\end{array}$ & Incentivized & 2.99 & 2.44 & -0.55 \\
\hline Yucatán & Incentivized & 3.38 & 2.39 & -0.99 \\
\hline Zacatecas & Incentivized & 3.02 & 4.35 & 1.33 \\
\hline
\end{tabular}

The states that did not implement any work-related incentive activities were Baja California. Campeche, Coahuila, Mexico City, Chiapas, Guanajuato, Guerrero, Sinaloa, Tabasco and Tlaxcala.

Fiscal stimuli demographically:

\begin{tabular}{|c|c|c|}
\hline \multicolumn{2}{|c|}{ Federal Entities that Implemented Fiscal Stimuli } & \multirow{2}{*}{$\begin{array}{l}\begin{array}{c}\text { Federal Entities that DID NOT } \\
\text { Implement Fiscal Stimuli }\end{array} \\
\text { 23. Baja California; }\end{array}$} \\
\hline 1. Aguascalientes; & 12. Nuevo León; & \\
\hline 2. Baja California Sur; & 13. Oaxaca; & 24. Campeche; \\
\hline 3. Chihuahua; & 14. Puebla; & 25. Coahuila; \\
\hline 4. Colima; & 15. Querétaro; & 26. Ciudad de México; \\
\hline 5. Durango; & 16. Quintana Roo; & 27. Chiapas; \\
\hline 6. Estado de México; & 17. San Luis Potosí; & 28. Guanajuato; \\
\hline 7. Hidalgo; & 18. Sonora; & 29. Guerrero; \\
\hline 8. Jalisco; & 19. Tamaulipas; & 30. Sinaloa; \\
\hline 9. Michoacán de Ocampo; & 20. Veracruz de Ignacio & 31. Tabasco; \\
\hline 10. Morelos; & de la Llave; & 32. Tlaxcala. \\
\hline & 21. Yucatán; & \\
\hline & 22. Zacatecas; & \\
\hline
\end{tabular}

\section{Discussion}

While unemployment increased in the face of new confinement measures to contain the spread of the Covid-19 pandemic at the end of the year, results for 2020 over 2019 from the National Occupation and Employment Survey (ENOE) New Edition with 88.0 \% face-to-face interviews and $12.0 \%$ telephone. interviews concluded that:

- During the year 2020, 22 of Mexico's 32 Federal Entities established a fiscal stimulus related to labor, through the deferral or exemption in the payment of the Payroll Tax, deferral or 
subsidy via refund of the Tax on Remuneration for Personal Work and with the application of an Emergency Plan for the Protection of Employment, respectively.

- The unemployment rate in Mexico in 2019 was 3,50 \% and in 2020 it was $4.58 \%$, i.e., increased due to the COVID 19 contingency by $1.08 \%$.

- While the above is true, it is also true that, in the year of 2019, the States that in 2020 received stimulus, on average reached an unemployment rate of $3.27 \%$, which with the pandemic rose by $0.9 \%$ to $4.17 \%$ compared to the States without fiscal stimulus that from having an unemployment rate of $3.78 \%$ in 2019 , increased to $5.01 \%$ in 2020 , i.e., $1.23 \%$.

- It is worth mentioning that during the second quarter of 2020, the period when the tax incentives began to be applied, total unemployment was 2,263,781 people; so far in 2021, the second quarter without any kind of incentive activity, reflected 2,425,506 unemployed people.

- Of the States that received fiscal stimulus, 4 of the 22 States managed to reduce their unemployment rate, with respect to last year, such cases were Hidalgo that in 2019 had $2.42 \%$ and in 2020, $2.22 \%$, Tamaulipas reduced from 3.43\% to $3.26 \%$, Veracruz from $2.99 \%$ to $2.44 \%$ and Yucatan that achieved it by $0.99 \%$ going from $3.38 \%$ to $2.39 \%$. And the rest of the 18 states increased by an average of only $1.21 \%$, equivalent to approximately 665,422 people.

- Of the states that did not receive fiscal stimulus, none of the 10 reduced their unemployment rate, and their unemployment rate over last year increased $1.23 \%$, equivalent to approximately 676,421 people.

- By State, the tax incentives applied were, in 7 States, the deferral of the payment of the Payroll Tax, in 13 States the exemption of the payment of the Payroll Tax. Payroll Tax on Remunerations for Personal Work Under the Direction and Dependence of an Employer and the Payroll Tax on Remunerations for Personal Work respectively, and Jalisco applied an Emergency Plan for the Protection of Employment, Querétaro established the deduction to the base of the Payroll Tax.

- The only State that managed to reduce its unemployment rate by placing the conditional "no unjustified dismissal" and applying the administrative facility/difference for taxpayers of the Personal Income Tax (Impuesto sobre Erogaciones por Remuneraciones al Trabajo Personal) was the State of Veracruz.

- States in 2020, respect to 2019 that applied the deferral as a fiscal stimulus increased unemployment by only $0.28 \%$, states that used the exemption increased $1.18 \%$. During 2020, Mexico was one of the countries that during the pandemic channeled the least fiscal stimulus in defense of employment and support to keep businesses from closing. Mexico allocated only $1 \%$.

- In contrast, Germany and Italy granted fiscal support close to $40 \%$ of their GDP. On the one hand, Germany condoned taxes for small companies and guarantee schemes for large companies, providing for a decrease in tax revenues of 33,5 billion euros, which, together with loan and guarantee programs worth 600 billion euros, managed to raise its 
unemployment rate by $0.9 \%$. On the other hand, Italy approved a tax cut that affected 16 million workers and managed to reduce its unemployment rate by $0.6 \%$.

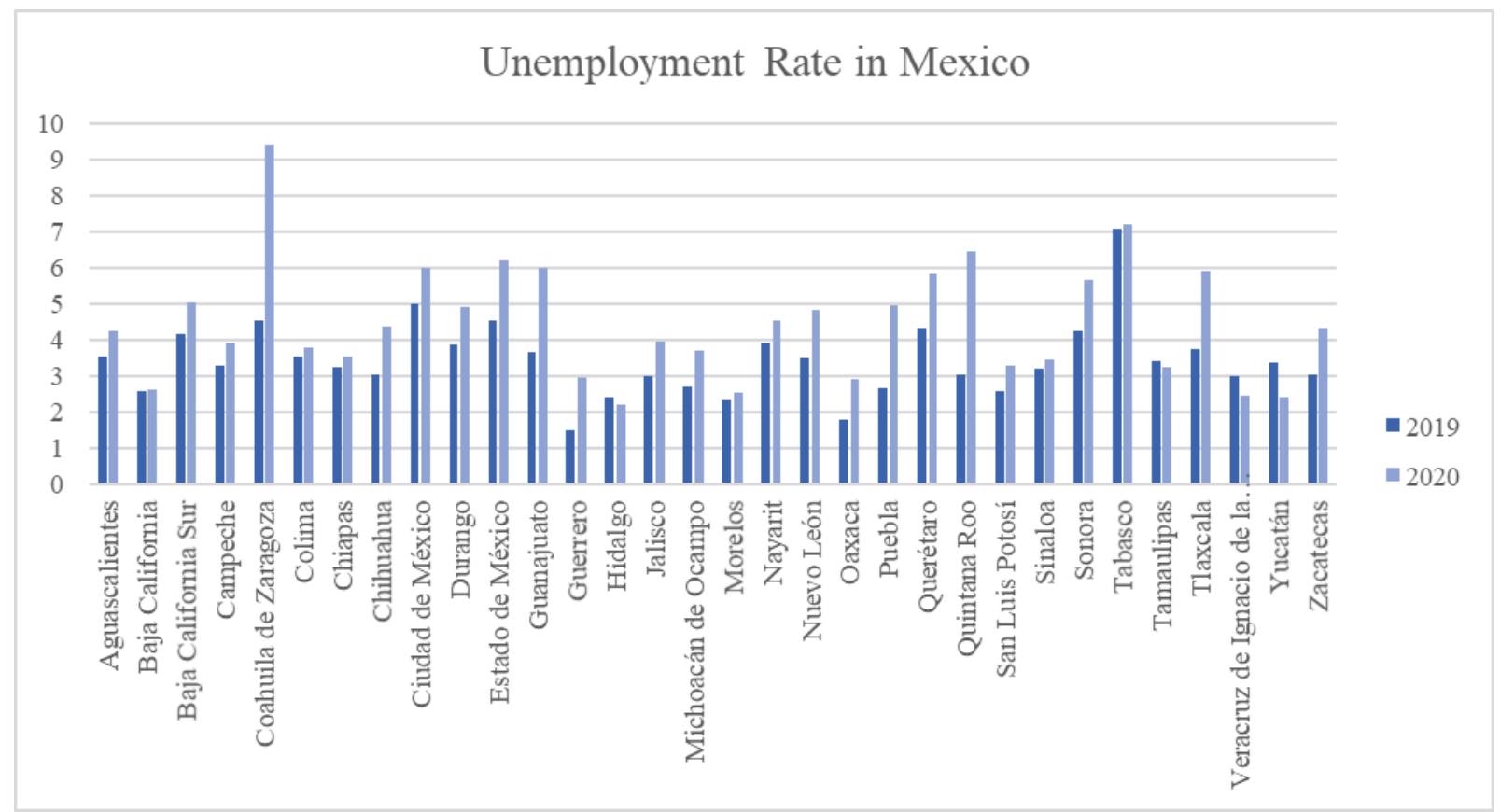

Figure 2. Graph of the Unemployment Rate in Mexico, years 2019 and 2020.

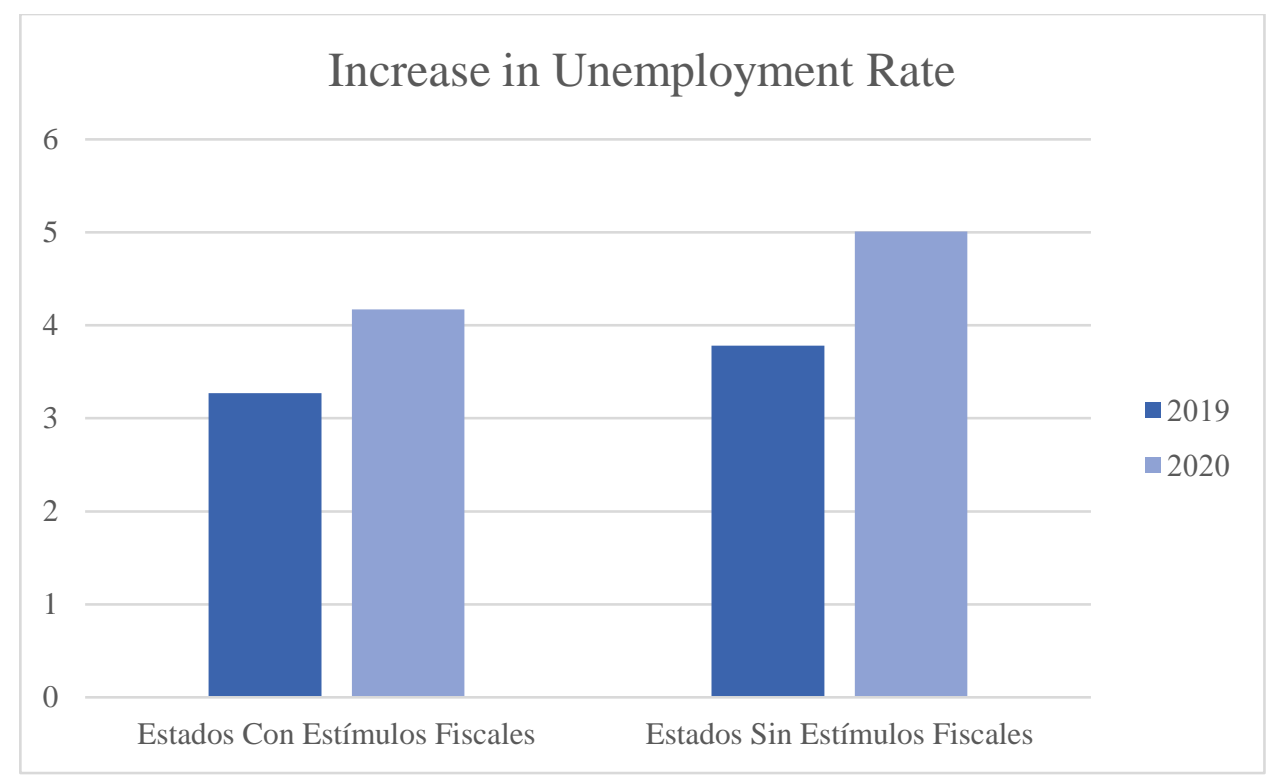

Figure 3. Graph on the Increase in Unemployment Rate in Mexico, years 2019 and 2020.

After analyzing the unemployment rate of the States that implemented a fiscal stimulus related to labor, such as the deferral or exemption in the monthly payment of the Payroll Tax or the Tax on Payments for Remunerations for Personal Work, we can conclude that although in the States where these stimuli were implemented there was a decrease in the unemployment rate, compared to the States that did not, it would be better to take other countries such as Germany and Italy as a model. The stimulus was aimed at small and medium-sized companies, classified according to 
the number of workers and the amount of sales they generate. This is important because such companies are of particular importance to national economies, not only for their contributions to the production and distribution of goods and services, but also for their flexibility in adapting to technological changes and their potential to generate employment. They represent an excellent means to promote economic development and a better distribution of wealth. The most important thing is the condition that all activities establish for companies to be able to benefit from this support and this is that they must not reduce their workforce during the contingency, so that employers, workers and their families have the possibility of maintaining their dignified life and the government fulfills its obligation to ensure the welfare of citizens.

\section{Conclusion}

Following the adoption of the neoliberal model in Latin American economies during the 1980s and 1990s, the State has been playing an increasingly marginal role in job creation and labor market regulation and has ceded its functions to the forces of free supply and demand. However, it cannot neglect it completely. Beyond the fact that the primary function of the State is the satisfaction of public needs, the promotion activity seeks that individuals voluntarily carry out a certain activity that contributes to the public interest, so that with this established benefit of the Tax on Personal Income Tax, even though this could represent a negative tax collection impact, the productive sectors will continue to contribute to growth, development and positioning, in addition to avoiding unemployment. The balance estimated by the ENOE on the labor market is that the working population found itself in a more precarious situation as a consequence of the pandemic; however, although unemployment. increased, in view of this panorama, the benefits of applying incentive activities with fiscal stimuli in 2020 were reflected in the fact that the increase in unemployment was much lower in the States that promoted a fiscal stimulus, even in 4 of them it was possible to reduce this index, while in the States without stimulus, the increase was regrettable. A broader policy of support and incentive activities is needed. Mexico implemented one of the lowest fiscal responses to the covid-19 emergency, which inevitably led to a deterioration in the quality of life of the working population and a greater polarization of their income. Stimuli were good but insufficient for the situation we are facing: the possible extension of fiscal stimuli should be evaluated. The risk of the absence of fiscal stimuli continues to materialize, since in Mexico the promotion activities only lasted a few months, resulting in layoffs, economic contraction and the disappearance of companies. The promotion of employment and economic growth must be approached from multiple fronts; administrative activity reflected in promotion and stimulus activities, despite its limited constitutional reference, can work in coordination with broader structural reform initiatives to stimulate the subsistence of jobs.

\section{Notes}

i Feix, N. (2020). México y la crisis de la COVID-19 en el mundo del trabajo: respuestas y desafíos. Organización Internacional del Trabajo, 2. https://www.ilo.org/wcmsp5/groups/public/---americas/---rolima/---ilo-mexico/documents/publication/wcms_757364.pdf. 
ii Hernández, N., Clark, P., \& Torres, L. (2021). El mercado laboral mexicano tras un año de pandemia. Instituto Mexicano para la Competitividad, A.C., 10-12. https://imco.org.mx/wpcontent/uploads/2021/05/202518-IMCO-analiza-Mercado-laboral-tras-un-an\%CC\%83o-depandemia_Documento.pdf.

iii Constitución Política de los Estados Unidos Mexicanos, Diario Oficial de la Federación, México, 05 de Febrero de 1917.

iv Estrella, V. (2021). Tras pandemia, solo cinco estados amortiguan desocupación al cierre del 2020. El Economista. https://www.eleconomista.com.mx/estados/Tras-pandemia-solo-cinco-estados-amortiguandesocupacion-al-cierre-del-2020-20210121-0150.html.

${ }^{\vee}$ Zepeda, C. (2021). El desempleo en México se ubicó en 4\% en junio. La Jornada. https://www.jornada.com.mx/notas/2021/07/26/economia/el-desempleo-en-mexico-se-ubico-en-4-enjunio/.

vi Garrido, I. (2014). La Protección del Interés General por parte de la Administración y del Derecho Administrativo. Instituto de Investigaciones Jurídicas de la UNAM. https://archivos.juridicas.unam.mx/www/bjv/libros/9/4331/14.pdf.

vii Padierna, D. (2017). B. Desempleo en México. Gaceta de/ Senado, LXIII/1PPO-69/59784. https://www.senado.gob.mx/64/gaceta_del_senado/documento/59784.

viii Morales, Y. (2021). México y Uganda tienen los estímulos fiscales más modestos ante la pandemia: IIF. El Economista. https://www.eleconomista.com.mx/economia/Mexico-y-Uganda-con-los-estimulos-fiscalesmas-modestos-ante-pandemia-20210115-0004.html.

ix Cota, J., \& Mendoza, E. (2020). COVID-19 y el empleo en México: impacto inicial y pronósticos de corto plazo. Contaduría y administración, 65(4).

x Lozano, L., Lozano, S., \& Robledo, R. (2020). Desempleo en tiempo de COVID-19: Efectos socioeconómicos en el entorno familiar. Journal of Science and Research. https://dialnet.unirioja.es/descarga/articulo/7635978.pdf.

${ }^{x i}$ Cota, R., \& Navarro A. (2016). Análisis del concepto de empleo informal en México. Análisis Económico, Núm. 78, vol. XXXI.

xii Feix, N. (2020). México y la crisis de la COVID-19 en el mundo del trabajo: respuestas y desafíos. Organización Internacional del Trabajo, 2. https://www.ilo.org/wcmsp5/groups/public/---americas/---rolima/---ilo-mexico/documents/publication/wcms_757364.pdf.

xiii Samaniego, N. (2020). El Covid-19 y el desplome del empleo en México/The Covid-19 and the Collapse of Employment in Mexico. Economía UNAM, 17(51), 306-314.

xiv Galaz, Y., \& Ruiz, U. (2020). Apoyos y estímulos fiscales otorgados por Estados en respuesta al COVID19 publicados en sus periódicos oficiales. Impuestos y Servicios Legales.

https://www2.deloitte.com/content/dam/Deloitte/mx/Documents/tax/flashes-2020/Apoyos-y-estimulosfiscales-por-estados-por-COVID19.pdf.

\section{References}

Constitución Política de los Estados Unidos Mexicanos, Diario Oficial de la Federación, México, 05 de Febrero de 1917. 
9 Implementation of Tax Incentives to Avoid Unemployment Caused by the Economic Situation due to the COVID-19 Health Emergency in Mexico

Cota, J., \& Mendoza, E. (2020). COVID-19 y el empleo en México: impacto inicial y pronósticos de corto plazo. Contaduría y administración, 65(4).

Cota, R., \& Navarro A. (2016). Análisis del concepto de empleo informal en México. Análisis Económico, Núm. 78, vol. XXXI.

Estrella, V. (2021). Tras pandemia, solo cinco estados amortiguan desocupación al cierre del 2020. El Economista. https://www.eleconomista.com.mx/estados/Tras-pandemia-solo-cinco-estadosamortiguan-desocupacion-al-cierre-del-2020-20210121-0150.html.

Feix, N. (2020). México y la crisis de la COVID-19 en el mundo del trabajo: respuestas y desafíos. Organización Internacional del Trabajo, 2. https://www.ilo.org/wcmsp5/groups/public/---americas/--ro-lima/---ilo-mexico/documents/publication/wcms_757364.pdf.

Gaceta Oficial de Puebla. (2020). http://periodicooficial.puebla.gob.mx/media/k2/attachments/T_2_15012021_C.pdf.

Galaz, Y., \& Ruiz, U. (2020). Apoyos y estímulos fiscales otorgados por Estados en respuesta al COVID-19 publicados en sus periódicos oficiales. Impuestos y Servicios Legales. https://www2.deloitte.com/content/dam/Deloitte/mx/Documents/tax/flashes-2020/Apoyos-yestimulos-fiscales-por-estados-por-COVID19.pdf.

Garrido, I. (2014). La Protección del Interés General por parte de la Administración y del Derecho Administrativo. Instituto de Investigaciones Jurídicas de la UNAM. https://archivos.juridicas.unam.mx/www/bjv/libros/9/4331/14.pdf.

Hernández, N., Clark, P., \& Torres, L. (2021). El mercado laboral mexicano tras un año de pandemia. Instituto Mexicano para la Competitividad, A.C., 10-12. https://imco.org.mx/wpcontent/uploads/2021/05/202518-IMCO-analiza-Mercado-laboral-tras-un-an\%CC\%83o-depandemia_Documento.pdf.

Padierna, D. (2017). B. Desempleo en México. Gaceta de/ Senado, LXIII/1PPO-69/59784. https://www.senado.gob.mx/64/gaceta_del_senado/documento/59784.

Lozano, L., Lozano, S., \& Robledo, R. (2020). Desempleo en tiempo de COVID-19: Efectos socioeconómicos en el entorno familiar. Journal of Science and

Research. https://dialnet.unirioja.es/descarga/articulo/7635978.pdf.

Morales, Y. (2021). México y Uganda tienen los estímulos fiscales más modestos ante la pandemia: IIF. El Economista. https://www.eleconomista.com.mx/economia/Mexico-y-Uganda-con-los-estimulosfiscales-mas-modestos-ante-pandemia-20210115-0004.html.

Samaniego, N. (2020). El Covid-19 y el desplome del empleo en México/The Covid-19 and the Collapse of Employment in Mexico. Economía UNAM, 17(51), 306-314.

Zepeda, C. (2021). El desempleo en México se ubicó en 4\% en junio. La Jornada. https://www.jornada.com.mx/notas/2021/07/26/economia/el-desempleo-en-mexico-se-ubico-en-4en-junio/. 